\title{
Maria Wojtak*
}

iD https://orcid.org/0000-0003-4537-2732

\section{Linguistic and Stylistic Polyphony of Occasional Journalism}

This article was intended as an attempt at defining a specific press publication in the form of a genre collection. ${ }^{1}$ It was the supplement to the Tygodnik Powszechny weekly (issue 29 of 2018) entitled "Festiwal Stolica Języka Polskiego" [Capital of Polish Language Festival]. The publication took the form of a press magazine, as apart from the festival program it included in the second page of the cover an editorial, i.e. an announcement text (supplemented with a table of contents and the festival program), and a few other texts representing various press genres, e.g. interviews, reviews provided in the form of press articles, commentaries, and, as components of the micro-collection, the bios of selected participants of the festival. Thus, it offered a co-occurrence of specific statements in a specific place and time which are typical for such a collection. Another distinctive feature of the collection was that the whole could be assigned the function of announcing a cultural event, i.e. the festival, and the function of promoting it.

For the perspective of description used in this study, the genological status of the publication was of a secondary importance. What was most important was the explanation of the term 'polyphony' used in the title. I thus refer to my own proposal of characterising the stylistic diversity of traditional press and interpreting this phenomenon from the discursive perspective. ${ }^{2}$ There is no need to extensively discuss the theoretical

* Professor, Maria Curie Skłodowska University in Lublin, Faculty of Humanities, Institute of Polish Philology, Department of Polish Language and Dialectology, e-mail: maria.wojtak@poczta.umcs.lublin.pl.

1 For a discussion of the notion of a genre collection and the genre in the form of a collection vide M. Wojtak, "Gatunek w formie kolekcji a kolekcja gatunków", Poznańskie Spotkania Językoznawcze 2006, vol. 15, pp. 143-152; idem., Współczesne modlitewniki w oczach językoznawcy. Studium genologiczne, Biblos, Tarnów 2011, pp. 21-22.

2 M. Wojtak, Głosy z teraźniejszości. O języku współczesnej polskiej prasy, Wydawnictwo Wyższej Szkoły Przedsiębiorczości i Administracji, Lublin 2010 [Unless indicated otherwise, English quotations were translated from Polish]. 
backbone, which I have addressed in several of my books, ${ }^{3}$ so allow me only to restate that "I will [...] understand [voices] as expressions (or their fragments or collections) shaped in pragmatic (i.e. for communicational purposes) and linguistic (stylistic) terms published in traditional press which co-form the polymorphic nature of the message."4 Some of those voices take the form of expressions which typify the patterns of specific genres. It is worth adding that "[...] the notion of voice seems to be an independent phenomenon, which cannot be reduced to language, style, nor discourse." There is o ne more important initial ascertainment: "The press discourse, considered as a mosaic of various discourses, only quoted or absorbed and transformed [...], assigns various functions to the same linguistic measures, including them both within individual forms of communication (genres), and in specific expressions."

Allow me to reiterate that in the selected perspective it is not so much the question of the genre form of the analysed expressions as their immersion in discourse, i.e. specific communicative practices typical for contemporary press which form the complex network of strategies, goals and forms of communication, which, in turn, determine the form of contemporary press. ${ }^{7}$

The analytical objective of this paper is to present the communicative polyphony of a specific collection of journalistic expressions, that is, those which interpret a specific reality and are used for convincing readers to accept that interpretation. Individual communicational streams will be referenced in the titles of the paper's sections. Both the wordings of the titles and the interpretations signalled by those constitute the author's propositions.

\section{Polyphony of the editorial}

The collection's introductory text exhibits the qualities of an editorial, i.e. primarily the voice of the editor-in-chief (or another representative of the editorial board). ${ }^{8}$ An editorial is used to indicate the focus of an issue and it is an interface genre

3 Ibid., pp. 13-25; idem., Rozłożone gazety. Studia z zakresu prasowego dyskursu, języka i stylu, Wydawnictwo Uniwersytetu Marii Curie-Skłodowskiej, Lublin 2015, pp. 31-44; 95-105.

4 M. Wojtak, Głosy z teraźniejszości..., p. 9.

5 Ibid.

6 Ibid., p. 11.

7 M. Wojtak, Rozłożone gazety..., pp. 203-217. The analysed collection lacks genre specimens, i.e. original and surprising expressions, even if those might had included signals of their genre affinity. A discussion of those, vide: B. Bogołębska, "Prasowe eksperymenty gatunkowe", [in:] Gatunki i formaty we współczesnych mediach, W. Godzic, A. Kozieł, J. Szylko-Kwas (eds.), Wydawnictwo Poltext, Warszawa 2015, pp. 71-81.

8 On the genre features of an editorial vide M. Wojtak, Analiza gatunków prasowych. Podręcznik dla studentów dziennikarstwa i kierunków pokrewnych, Wydawnictwo Uniwersytetu Marii Curie-Skłodowskiej, Lublin 2008, pp. 96-108. 
of an announcement, commentary, review and essay. That is because the process of announcing, as a communicative practice, consists of informing readers of press material, as well as of advertising it, notifying readers about selected components of reality (usually with elements of interpretation), and directing their reading.

The analysed text, entitled "Roztocze. Wschód Kreatywności", was not a classical editorial mainly due to its author. This function was fulfilled not by Michał Sowiński, the supplement's editor-in-chief, but by Piotr Duda, the festival's director. Actually, the only element that connected the text to the conventions of an editorial was the following fragment: "We are going to discuss that in Szczebrzeszyn. Now, I would like to invite you to read our supplement, which presents the guests of this year's Festival, and offers a closer look into the world of the artists of the Skamander group, the patrons of the $4^{\text {th }}$ edition of the Festival."

That invitation to read the publication edited as a statement of a collective sender ("our supplement") could be interpreted as a communication mask (the communicative roles assumed by the author). Another, and clearly ore important, role was to act as the manager of the (cultural) event. Traditional editorials do not feature such a voice.

The Festival's director discussed the event in business and marketing terms. The notional and stylistic decorum was clearly marked, though one could not argue that the text fulfilled all the characteristics of marketing discourse. ${ }^{9}$ The style is subdued and subtle. The only keywords (or, actually, witness words, i.e. lexical forms connected with naming the reality of a specific epoch) that appeared in it were "iwent" [event] (with that particular spelling), creativity (the creative sector), the culture industry, project, and potential for innovation. The Festival was presented as an implementation of the vision of the actions of "local leaders", actions undertaken with passion and engagement, and with belief in their success. The word "success" was not actually used, yet the director's text was a success story.

To emphasise the indicated polyphonic nature of Piotr Duda's statement, allow me to quote the following fragments (I emphasized the lexis of marketing discourse in bold):

A few years back, after a meeting with a group of local leaders in Szczebrzeszyn, I described my vision of organising a literary event of national significance. It triggered huge enthusiasm and eagerness to collaborate. At that time, all we had was hope and a lot of work to be done.

9 This discourse was defined in the monograph: M. Smoleń-Wawrzusiszyn, Polskie dyskursy marketingu. Perspektywa lingwistyczna, Wydawnictwo Katolickiego Uniwersytetu Lubelskiego, Lublin 2018. 
Today, as I am writing these words, we have already organised three exceptional editions of the Capital of Polish Language Festival. They happened thanks to the efforts and engagement of many people to whom I am extremely grateful. [...] Together we created an art event which is authentic, smart, original, and which is not just another "iwent". It builds a sense of value; it presents the beauty of art and it offers opportunities for the development of one of the most beautiful regions in our country. [...]

New challenges await us. We wish to engage in a discussion on further development, which would capitalise on the existing potential of the Festival. [...] I have worked for over 20 years in the culture industry and I am a proponent of developing projects which carry a potential for innovation and stimulate the development of the creative sector. That is why we prepared the publication Roztocze. Wschód Kreatywności specifically for the Festival. It is an attempt at answering the question whether our activities (the Festival) may inspire other initiatives. [...] I am certain that in Roztocze the culture industry and the creative sector can develop, and it can propel the entire region.

I do not intend to evaluate that style in this paper, though it did not make the greatest of impressions. By assuming the descriptive approach, I only conclude that the first component of the stylistic polyphony of the analysed collection was the voice of a culture manager devoted to his activities. He perceived the project he described (a cultural event) in business terms, which was the dominant perspective, and in humanistic terms (as a value). The Festival, he was eager to indicate, was not just another "iwent".

The other voices further specified and solidified this perspective.

\section{Poet about poets}

In the interview Pięciu wspaniałych, moderated by Michał Sowiński and Justyna Sobolewska, Piotr Matywiecki spoke of the poets of the Skamander group. ${ }^{10}$ His somewhat controlled voice (mind you, an interview is normally a dialogue, while here it was a polylogue) described the significance of the poetic group, the fortunes of its poet-members, their by the readers, and the selected components of their styles. Matywiecki's statements did resonate with some literary criticism (which, actually, is in line with his profession), yet a personal tone was the stylistically dominant feature of the interview.

Matywiecki spoke about the significance of the group in the literary community as follows: "Skamanderers very quickly took the central spot in the literary community, becoming authority figures in poetry. After only a few years, they be-

10 "Pięciu wspaniałych", interview with P. Matywiecki by M. Sowiński, J. Sobolewska, Tygodnik Powszechny 2018, issue 29, "Festiwal Stolica Języka Polskiego" supplement, pp. 4-7. 
gan anointing writers of the younger generation." The ideological attitude was expressed in the following words: "Despite their initial anarchistic attitude, they were close to traditional Polish patriotism." The approach of readers to selected members of the group, Tuwim in particular, was evident in the following fragment: "If Tuwim had received the Nobel Prize before the Second World War, it would have been considered an insult by Polish intelligentsia. No one offers the Nobel Prize to Homer. Tom Mann, sure, why not, but Tuwim?"

The following remarks of Matywiecki referred to the Skamanderers' mode of work: (1) "I have to agree with Miłosz that Young Poland damaged the syntax of Polish poems, while the initial works by Skamaderers were, in technical and structural terms, at a considerably higher level"; (2) "Due to his classical rhythms and rhymes [Lechon - M.W.] was afraid of being labelled a traditionalist. Yet despite the anachronistic nature, his verse was of superb quality. He was the master of the sentence segment, which gave even traditional poems dynamism and strength"; (3) "He was not a man of simple emotions [Słonimski M.W.] and yet he wrote sentimental poems which emanated intellectual cool. He was probably the most anachronistic among the five poets, but his early mighty epic poems [...] resembled those of the surrealist French poets or futurists."

By revealing the point of view of both a literary critic and a poet, Matywiecki presented Skamaderers as the masters of words, yet, mind you, in his own peculiar manner.

\section{Apologia of genre literature}

Another voice which co-formed the analysed collection was the article by Konrad Janczura entitled "Horror zwyczajności". "It unequivocally followed the principles of a classical press article, though it also included the elements of the poetics of a review. That came as no surprise since it was a text concerning the literary works of a specific author. Already the lead provided an initial presentation of the author: "Wojciech Chmielarz is a writer who suggestively describes the murky underbelly of the Polish reality concealed under a friendly mask." The bio attached to the article indicated that Chmielarz was a prose writer and journalist, and the author of nine crime stories, with the most recent published in 2018, entitled Żmijowisko.

The author of the article began with a thesis which he tried to prove in the subsequent sections of the article. ${ }^{12}$ Specifically, he indicated the value of genre literature through the following statement:

11 K. Janczura, "Horror zwyczajności", Tygodnik Powszechny 2018, issue 29, "Festiwal Stolica Języka Polskiego" supplement, pp. 10-11.

12 Vide K. Wolny-Zmorzyński, A. Kaliszewski, "Artykuł publicystyczny", [in:] Słownik terminologii medialnej, W. Pisarek (ed.), Universitas, Kraków 2006, p. 11, which includes the following observation: "The content of an article usually follows an author's pre-defined which she/he 
There are probably no more people who need convincing about the value of genre literature. Gombrowicz's mockery of Sienkiewicz as the "primary example of a secondary writer" sounds rather pretentious than witty (eventually Gombrowicz stated that belles lettres was for wimps). Even if the division into primary and secondary literatures had ever existed, the writers of horror, crime, love or dramatic novels have in recent years skilfully emancipated themselves from that secondary classification. [...]

His [Chmielarz's] prose completely [...] fulfils the genre conventions; it is consistent and disciplined, and it does not demand any "higher" instance appreciation.

Having included Chmielarz in the group of those emancipated writers, the author of the article sought in him and his writings such qualities which would confirm his initial diagnosis: "An unequivocally solid and skilful craftsman with words"; "[...] any excess emotionality common for belles lettres is foreign to him"; "It would be also difficult to find in his works any pretentious symbols or obtrusive cultural allusions"; "[...] Chmielarz focusses [...] on developing a thick and carefully woven story in which every now and again there emerge problems typical for the Polish society: racism, xenophobia and chauvinism"; "The language consistently used by the author has always been simple, saturated with humour, and his typical self-mockery."

The articles concluded suggestively: "Therefore, if you were to find a Polish author who could be put side by side with Jo Nesbø or Philip Kern, then Wojciech Chmielarz would be your perfect choice."

\section{Linguistic elegance in the works of a specific writer}

The next voice was also conveyed in a journalistic frame. That initial ascertainment applies to the article by Katarzyna Trzeciak entitled "Ostrze stylu" ${ }^{13}$ Already the lead indicated to readers the topic and the attitude of the author: "Rylski's linguistic elegance has nothing to do with nostalgic escapism. It is radical, almost domineering, as it holds a fundamental importance for the community."

In describing the writer's style, the journalist introduced a whole array of linguistic devices used for expressing admiration. She drew them mainly from reader opinions, by quoting or paraphrasing them and supplementing them with refer-

proves based on problem descriptions indicating facts or applying generalisations." The genre characteristics of an article and its polymorphic character are discussed in more detail in: M. Kasiak, "Architektonika tekstów dziennikarskich. Refleksje strukturalne wokół meta- i paratekstu artykułu publicystycznego", [in:] Gatunki i formaty..., pp. 84-86.

13 K. Trzeciak, "Ostrze stylu", Tygodnik Powszechny 2018, issue 29, "Festiwal Stolica Języka Polskiego" supplement, p. 12. 
ences to a review. The expression "the virtuoso of words" was the most general one she used. Among the quoted epithets, which co-formed to the poetics of amazement, the author included the following lexical forms: "arch stylist", "recognisable style", and "refined Polish language."

The interpretative part included the following fragments, which should be understood, it would seem, as attempts at justifying the praise. Consider the selected fragments:

Rylski has many of those and similar labels. Sometimes, they are invoked almost automatically, as an ID which is to name and place the writer in line with other Polish writers. "Eustachy Rylski, the style guy."

And the linguistic elegance has nothing of the nostalgic escapism from the world of live speech towards solidified stylisations. Rylski's attitude is radical, domineering even, and his elegance is closer to the sharpness of a dagger than to a dusty pen.

The author returned to linguistic matters upon discussing (in short) Rylski's most recent novel entitled Blask, in which the writer "drew a vision of a declining national community controlled by a shadow of an absent dictator." Allow me to refer to the final paragraph of the article, which bore many qualities of a review:

Blask is a novel on the importance of language, which is why the style has particular significance in it. If the elegance of speech has the sharpness of a dagger, then in Blask it is used for cutting the manipulative clichés of communication. The ostentatious attachment to style is, therefore, an expression of a distance towards the devaluation of speech. And the distance is ensures the place from which criticism stems-an attitude necessary for triggering change.

The analysed expression features the attitude of the journalist who used other people's words as the basis for her strong private interpretations. It was a very suggestively sounding voice. It perfectly fulfilled the advertising purpose of the entire collection.

\section{Poetry at the borderline of worlds}

I apply that label to the voice of Katarzyna Trzeciak in the article entitled "Atomy języka," ${ }^{14}$ which referred to the poetry of Urszula Zajączkowska, a poet and a botanist, "whose works combine the attributes of science with the records of aesthetic experiences."

14 K. Trzeciak, "Ostrze stylu", Tygodnik Powszechny 2018, issue 29, "Festiwal Stolica Języka Polskiego" supplement, p. 15. 
The author formulates the starting thesis quite clearly and suggestively: "The opposition between nature and culture continues, despite many efforts, to constitute one of the most tenacious frameworks of our thinking." The following fragment of the article illustrates the attitude of scientists towards the reality they study, and the manner in which they express it in scientific texts:

The division between the orders [of nature and culture - M.W.] also impacts the language-naturalness connotes genuineness and constancy, thus serving as a final and indisputable argument. Culturalness is sometimes associated with falseness, so it is sometimes unconvincing as a layer encapsulating the real world.

That tendency of language to create opposing orders is, fortunately, ever so often abated by post-humanistic research, which hallmarks the dusk of anthropocentric speech and the resulting ontological certainty. Yet the language in which we formulate the research is still marked with our all-encompassing human perspective.

One peculiarity of Zajączkowska's poetry is the attempt at crossing the line between science, where language stems from the instrumental mind (according to the author), and art, as a "cognitively reliable dimension." The poet includes " $19^{\text {th }}$ century etchings from biology handbooks with her commentary" in her poetry collection. The following journalistic interpretations apply to the existence of a borderline between the worlds:

She wrote, for example: "The only thing that keeps me going is the fact that sometimes a perfect blob of tea appears on a graph and a weasel cuts through a cable in the Large Hadron Collider." The poet looks at etchings but sees in them something which is not the core, which appears in a situation which from the perspective of science has no significance whatsoever. The scientific approach protects against this, as it uses language which organises experience. There forms a screen from behind which one cannot see "that here and now/ a drop/ falls on a leaf."

Poetry, according to Zajączkowska, can transcend the divisions developed on the basis of the scientific description of the world in which people studying nature only try to expand their rule. That does not, however, mean that poetry describes the joyful coexistence of people and non-human organisms. Mind you, harmony is but a human construct. The coexistence and cooperation of space present in both of Zajączkowska's collections constitute a not completely tension-free coexistence in the land of mildness. [...]

Her poetry, by focussing on the finest elements, fragments and atoms of existence throws the order of scientific divisions out of balance. Therefore, language is not so much in opposition to the discourses of science but rather it serves to diminish their categorical nature and to open them to new experiences. Only when we realise that we need many languages and neither is self-sufficient, can we transcend the hierarchical vision of humans and nature. 


\title{
Journalistically transformed child's voice
}

I shall devote this part of the study to a discussion of the voice of a journalist who interprets various phenomena associated with children's speech. This will be a discussion of the collection's closing article by Katarzyna Stolarczyk, entitled "Dzieci mówią lepiej" [Children talk better]. ${ }^{15}$ The title itself reflects the author's non-conventional attitude. According to the social stereotype, children speak worse. They do not always pronounce individual sounds and their clusters properly, they are not familiar with grammar rules, and their vocabulary is deficient. So where did that article's thesis on the "better" quality of their speech come from?

The author was able to perceive the phenomena she discusses in such a way because in her observations and remarks she refers to the worlds behind words, i.e. to children's thinking, which is reflected in their statements. The beginning of the article already defined the perspective:

\begin{abstract}
"A child is born thanks to the politeness of the dad!" spurted Julka, a five-year-old, and I froze. It was not the first time a child had stopped me in my stride. I have often exited the kindergarten with a head full of children's thoughts, broken sentences or words which suddenly assumed new meanings. Each time they are combined in absolutely non-obvious ways, with the addition of their trademark nonchalance. Children mould words like they do with Play-Doh. They are word-formation artists, the difference being their works are not devised-they are fresh, authentic and extremely creative.
\end{abstract}

The author wondered about the sources of the observations and associations expressed in children's words, indicating their originality by using specific examples. That did not only apply to the form but to the way in which a child reacts to specific stimuli in the form of questions or to a generally defined situation. The first case was illustrated in the following fragment: "I once asked Kalinka: 'Who is the first lady?' Kalinka responded immediately: 'Oh, but a lady doesn't always have to be first, because if she's late, then she's second.' Try to hold it in and not burst out laughing." Another one was presented in a fragment in which the author described a conversation about taboos with a group of three-year-olds: "I began the talk trying to avoid the most difficult topics. Suddenly I noticed a girl staring at me. I heard: 'But, ma'am, when someone is dying, you have to hug them really tight.' The room went silent."

Part of the author's narration was devoted to the presentation of examples of lexical innovations. For example, she quoted a child's reaction to the sight of dead bird: "Oh, daddy, look, what a nice corpsee." Immediately followed by an anecdote:

15 K. Stolarczyk, "Dzieci mówią lepiej", Tygodnik Powszechny 2018, issue 29, "Festiwal Stolica Języka Polskiego" supplement, pp. 21-22. 
“'Mum, sing me the song about the little cow', asked a boy. 'About the little cow?' asked the surprised mother. The boy went on to sing: 'Śpiewajcie i grajcie mu, małe muuu, małe muuuu!"”. [A Polish Christmas carol where the word "mu", i.e. "to him", is elongated, resembling the sound a cow makes - translator's note]

The following anecdotes include specifically selected examples of freshness in children's perception of the world. Consider the following fragment as an illustration:

When Sir Ken Robinson, an excellent writer and a master of creativity and innovation, decided to seek inspiration, he set off to travel the world visiting children at schools and kindergartens. [...] At one school, he participated in a drawing class. At some point the teacher came up to one of the pupils and asked her what she was drawing. The pupil, without stopping her work, responded: "I am drawing God." Clearly amused, the teacher said: "But no one knows what God looks like." To which the girl responded calmly: "Well, in a minute they will."

Why did I quote the exchange? Because it holds the essence of childness. It lifts all the barriers and borders which entangle our freshness of thought in our adult heads. I once asked children: "Which one of you usually takes the stage to speak?" and a small girl responded: "No one takes it, it belongs to everyone."

The article's conclusion includes the following message, or plea, if you will: "[...] we are together responsible for our children always being able to speak in their own voices. Because then the world will be not only more creative, but also better, not only in terms of word formation."

The analysed press texts feature a richness of cognitive perspective and points of view because the individual texts which form the collection discuss linguistic problems by juxtaposing statements of various origins (in press research, there exists the term "allowed voices"). They were quoted or transformed and included in press texts with specific genre determinants, usually of a press article, which I consider to be a typical quality of the press discourse. This enables one to bring forward the author's $I$ and make a text subjective, offering an individualised interpretation of the presented matters. Thus, the texts feature the simplifications and reductions of facts typical for any journalist, and a tendency to combine those to illustrate a starting thesis formulated as a certain judgement (and, less often, a hypothesis).

However, the journalistic polyphony had a special purpose in the discussed case: to inform people about the festival, which applied to various linguistic phenomena, and convince readers to participate in the exceptional event. Therefore, the use of various genres of expression (in their classic or modified versions) and the fact of combining them in a unifunctional collection was a fully justified editorial decision. 


\section{Bibliography}

Bogołębska B., "Prasowe eksperymenty gatunkowe", [in:] Gatunki i formaty we współczesnych mediach, W. Godzic, A. Kozieł, J. Szylko-Kwas (eds.), Wydawnictwo Poltext, Warszawa 2015, pp. 71-81.

Janczura K., "Horror zwyczajności", Tygodnik Powszechny 2018, issue 29, "Festiwal Stolica Języka Polskiego" supplement, pp. 10-11.

Kasiak M., "Architektonika tekstów dziennikarskich. Refleksje strukturalne wokół meta- i paratekstu artykułu publicystycznego", [in:] Gatunki i formaty we wspótczesnych mediach, W. Godzic, A. Kozieł, J. Szylko-Kwas (eds.), Wydawnictwo Poltext, Warszawa 2015, pp. 83-99.

"Pięciu wspaniałych", interview with P. Matywiecki by M. Sowiński, J. Sobolewska, Tygodnik Powszechny 2018, issue 29, "Festiwal Stolica Języka Polskiego" supplement, pp. 4-7.

Smoleń-Wawrzusiszyn M., Polskie dyskursy marketingu. Perspektywa lingwistyczna, Wydawnictwo Katolickiego Uniwersytetu Lubelskiego, Lublin 2018.

Stolarczyk K., "Dzieci mówią lepiej”, Tygodnik Powszechny 2018, issue 29, "Festiwal Stolica Języka Polskiego" supplement, pp. 21-22.

Trzeciak K., "Ostrze stylu”, Tygodnik Powszechny 2018, issue 29, "Festiwal Stolica Języka Polskiego" supplement, p. 12.

Trzeciak K., "Ostrze stylu”, Tygodnik Powszechny 2018, issue 29, "Festiwal Stolica Języka Polskiego" supplement, p. 15.

Wojtak M., Analiza gatunków prasowych. Podręcznik dla studentów dziennikarstwa i kierunków pokrewnych, Wydawnictwo Uniwersytetu Marii Curie-Skłodowskiej, Lublin 2008.

Wojtak M., “Gatunek w formie kolekcji a kolekcja gatunków”, Poznańskie Spotkania Językoznawcze 2006, vol. 15, pp. 143-152.

Wojtak M., Głosy z teraźniejszości. O języku współczesnej polskiej prasy, Wydawnictwo Wyższej Szkoły Przedsiębiorczości i Administracji, Lublin 2010.

Wojtak M., Rozłożone gazety. Studia z zakresu prasowego dyskursu, języka i stylu, Wydawnictwo Uniwersytetu Marii Curie-Skłodowskiej, Lublin 2015.

Wojtak M., Współczesne modlitewniki w oczach językoznawcy. Studium genologiczne, Biblos, Tarnów 2011.

Wolny-Zmorzyński K., Kaliszewski A., “Artykuł publicystyczny”, [in:] Słownik terminologii medialnej, W. Pisarek (ed.), Universitas, Kraków 2006, p. 11. 
Maria Wojtak

\title{
Językowa i stylistyczna wielogłosowość publicystyki okolicznościowej
}

\author{
Streszczenie
}

Artykuł jest pomyślany jako próba charakterystyki konkretnej publikacji prasowej, mającej kształt gatunkowej kolekcji. Jest to bowiem dodatek do „Tygodnika Powszechnego" (nr 29 z 2018 roku) pt. Festiwal Stolica Języka Polskiego. Publikacja ta powiela formę magazynu prasowego, gdyż oprócz programu festiwalu zawiera: editorial, wywiady, recenzje, teksty komentujące i biogramy wybranych uczestników festiwalu. Mamy zatem do czynienia z typowym dla kolekcji współwystępowaniem konkretnych wypowiedzi w określonym miejscu i czasie. Całości przypisać można funkcję powiadamiania o wydarzeniu kulturalnym (festiwalu) oraz funkcję promowania imprezy.

Autorka analizuje wspomnianą publikację w perspektywie dyskursywnej, a więc zwraca uwagę na określone, typowe dla współczesnej prasy praktyki komunikacyjne, tworzące skomplikowaną siatkę strategii, celów i form komunikacji, składających się na kształt współczesnej publicystyki.

Analitycznym celem artykułu jest pokazanie komunikacyjnej polimorficzności konkretnego zbioru wypowiedzi publicystycznych, a więc interpretujących określoną rzeczywistość i służących przekonaniu czytelników do tej interpretacji.

Poszczególne wypowiedzi są traktowane jako głosy, czyli komunikacyjnie (pragmatycznie) i formalnie ukształtowane typy działań językowych.

Słowa kluczowe: komunikacja, dyskurs, dyskurs prasowy, publicystyka, gatunek wypowiedzi.

\section{Linguistic and Stylistic Polyphony of Occasional Journalism}

Summary

The article was intended as an attempt at defining a specific press publication in the form of a genre collection. It was the supplement to the Tygodnik Powszechny weekly (issue 29 of 2018) entitled "Festiwal Stolica Języka Polskiego" [Capital of 
Polish Language Festival]. The publication utilised the form of a press magazine, as apart from the program of the festival, it also included: an editorial, interviews, reviews, commentaries and the bios of selected festival guests. Thus, it offered a cooccurrence of specific statements in a specific place and time which is typical for such a collection. The whole could be assigned the function of announcing a cultural event (the festival), and the function of promoting it.

The author analyses the publication from the discursive perspective, i.e. she focussed on specific communicational practices typical for contemporary press, which form a complex network of strategies, goals and forms of communication, which, in turn, form contemporary journalism.

The analytical objective of the paper was to present the communicational polyphony of a specific collection of journalistic expressions, that is which interpret a specific reality and were used for convincing the readers to accept that interpretation. Individual texts were treated as voices, i.e. in types of linguistic actions formed in communicational (pragmatic) and formal terms.

Keywords: communication, discourse, press discourse, journalist, text genre.

Maria Wojtak - professor at the Institute of Polish Philology, Maria Curie Skłodowska University in Lublin, member of the Polish Linguistic Society, the Linguistic Committee at PAS, the Academic Society at the Catholic University of Lublin, and of the Legal Language Team and the Religious Language Team at the Polish Language Council. Academic focus: stylistics (theoretical, practical, historical), history of language, normative grammar, textual studies, genology, and press research. She is the author of many articles and papers on, e.g. the formation of stylistic variants of Polish and their histories; the notions of genre, style, discourse; genre realisation, i.e. a text; descriptions of selected forms of religious, official and descriptions texts; and notions in linguistic etiquette. Major book publications: Dialog w komedii polskiej na przykładzie wybranych utworów z XVII i XVIII wieku (1993); Gatunki prasowe (2004); Głosy z teraźniejszości. O języku wspótczesnej polskiej prasy (2010); Współczesne modlitewniki w oczach językoznawcy. Studium genologiczne (Teolingwistyka series, vol. 9, 2011); O języku i stylu polskiego dramatu. Studia i szkice (2014); Rozłożone gazety. Studia z zakresu prasowego dyskursu, języka i stylu (2015). 